\title{
Study on the lithofacies of the second member of Tengger formation in Jiergalangtu of Erlian Basin
}

\author{
Niu Daming ${ }^{1}$, Fu Hang ${ }^{1}$, Zhang Yunfeng ${ }^{1}$, Li Yilin ${ }^{1}$ \\ ${ }^{1}$ Northeast Petroleum University, Daqing, china
}

\begin{abstract}
Through analyzing coring well observation and in combination with drilling data log sheet and the analysis of the test data, combined with the regional sedimentary tectonic evolution background of the second member of Tengger formation in Jiergalangtu of Erlian basin, the results show that lithic arkose and feldspathic lithic sandstone are developed in the study area. There are abundant sedimentary structures, mainly including parallel bedding, laminated bedding and massive bedding, etc. According to the analysis of sedimentary characteristics, nine lithofacies types and four vertical assemblages are summarized, which respectively reflect different microfacies environments: subaqueous distributary channel subaqueous distributary channel interestuarine bar sheet sand.
\end{abstract}

\section{INTRODUCTION}

Sedimentary rocks are loose sediments deposited in layers. Terrestrial, Marine and transcontinental facies can also be subdivided according to the structure. Lithofacies can be analyzed not only laterally but also longitudially, changing with time and space. Horizontally, the horizontal phase transition reflects the difference of sedimentary environment, and vertically, the vertical phase transition represents the geographical environment changes in the same area at different times.

In this paper, the author studies the lithofacies of the second member of Tengger formation in Jiergalangtu of Erlian basin ${ }^{[1,2,5]}$ through core observation, well logging, thin section analysis, etc., and according to different lithofacies combinations, the deposition process of different microfacies is reflected

\section{LITHOFACIES MARKS}

\subsection{Sedimentary structure and detrital component}

The sedimentary structure of the study area is rich, the water body is relatively deep during the deposition period, and a large number of plant fossils can be seen. Parallel bedding, groove cross-bedding, vein bedding, block bedding and wave bedding are widely developed. Four sedimentary microfacies are mainly developed: underwater distributary channel, underwater distributary channel, estuarine bar and sheet sand.

Based on the observation of the cast thin sections, the lithic arkose and arkose lithic sandstone are dominant in the second member of Tengger of Jiergalangtu. Quartz, feldspar (mainly plagioclase, potash feldspar), quartzite debris, andesite debris (Fig.1(a)), granite debris (Fig.1(b)) and so on are developed in this component. The types of cementation are quartz secondary augmentation cementation (Fig.1(c)), thin film cementation (Fig.1(d)), calcite pore cementation, calcite contact cementation (Fig.1(e)), chalmedite contact cementation(Fig.1(f)), calcite even crystal cementation(Fig.1(g)), anhydrite pore cementation, grain Mosaic cementation(Fig.1(h)), etc. Intergranular dissolution pores (Fig.1(i)) and ingranular dissolution (Fig.1(j)) pores were developed. According to the clastic component characteristics, the deposition period is far from the source area, so there is weak hydrodynamic force and the deposition rate is slow.
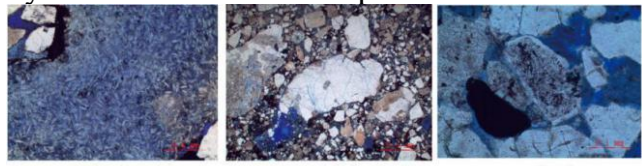

(b)
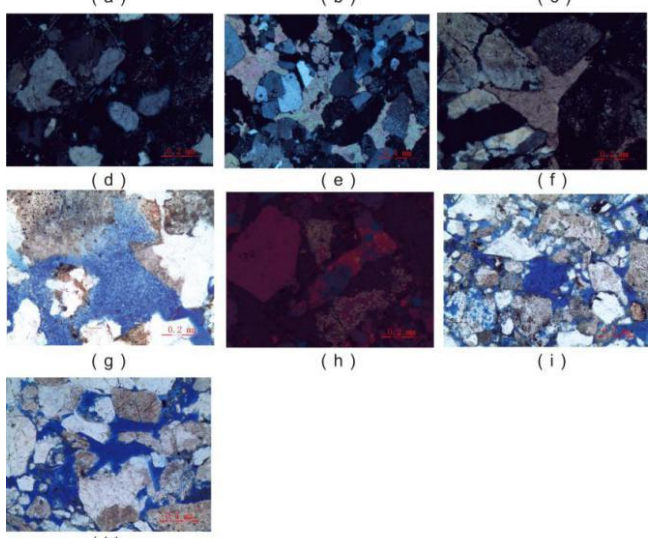

$(\mathrm{h})$

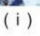

Fig.1. the cast sheet of the second member of Jiergalangtu in Erlian Basin

The author addresses: 706483712@qq.com

The corresponding author's e-mail address: 2711057181@qq.com,553758753@qq.com 


\section{LITHOFACIES DIVISION}

Through the detailed observation and description of several coring Wells in the Tengger formation of Jiergalangtu and the analysis of sedimentary characteristics such as lithology and sedimentary structure of the core, the author divides the Tenger Formation of Jiergalangtu into 9 different types of lithofacies.

(1) Parallel bedded sandstone facies (Sh) is mainly gray and brown coarse-fine sandstone. Flat bedding generally appears in a highly hydrodynamic environment. Through the migration of flat bed sand and the continuous rolling of sand grains on the bed surface, the horizontal fine bedding in a high flow state is revealed, and the stripping along the inside of the bed shows the stripping linear structure[3] .

(2) The fluted cross-laminated argillaceous siltstone facies (MFct) layers are interlaced and cut into the groove type, and the longitudinal profile is arc-shaped, while the transverse profile is fluted. The downward inclined direction of the laminae converges with the oblique direction, which is the result of underwater dune migration. Its lithology is mainly gray argillaceous siltstone.

(3) Wavy bedded sandstone facies (Sw) Brown coarse sandstone interbedded with silty mudstone. The layers are continuous wavy bedded and asymmetric bedded, which are caused by unidirectional water flow moving forward. It contains gravel and distributes along layers with a gravel diameter of $2-15 \mathrm{~mm}$.

(4) Mudstone facies (M) are mainly gray mudstone and silty mudstone, many of which are specular, indicating active tectonic movement. A small number of mudstones are calcareous mudstones, indicating that if calcium carbonate is mixed (25-50\%), hydrochloric acid will bubble up. The horizontal bedding indicates that the fine sediments are produced by hydrodynamically weak static underwater deposition.

(5) Multistage granular-supported conglomerate facies (Gcs) is characterized by poor gravel separation and round milling. In this facies, the size and composition of the gravel are varied, and the coarse gravel is also filled with fine-coarse sand and multistage granular-supported gravel. The poor connectivity between particles is the worst type of lithofacies.

(6) Argillaceous supporting floating conglomerate facies (Gmm) with high argillaceous content. Gravel with different particle sizes of $2-10 \mathrm{~mm}$ are suspended in mudstone matrix and arranged in parallel on the interface, which is debris flow deposition.

(7) Obliquely bedded sandstone facies (So) is composed of laminae that are obliquely intersected at the stratigraphic interface and are generated by water flow and wind. Therefore, in order to analyze the source direction, the inclination of oblique bedding can be understood. The lithology is mainly composed of gray and brown coarse sand and fine sandstone, which are well sorted and rounded.

(8) lapped bedding sandstone facies (Sc) fine sandstone lithology is mainly for the gray, in the process of sediment liquefaction, flowing water and the shear force of the gravity on the slope raise deposit slip, a layer of bedding structures through complex of "fold", so as to constitute a continuous open syncline and tight anticline formed by "lapped" state.

(9) The void between the sandy supported floating conglomerate facies (Gms) gravel is filled by fine sandstone and coarse sandstone as interstitials, and the gravel is suspended in sandy particles with poor gravel separation and gravel diameter of about $2-25 \mathrm{~mm}$, which belongs to the sand rich clastic flow deposition. It is a relatively good transport channel for oil and gas with good connectivity between particles.

\section{LITHOFACIES ASSOCIATION}

Lithofacies types reflect a single sedimentary process or process, while vertical assemblage reflects the characteristics of vertical assemblage of sedimentary environment[4,6]. The same facies types and backgrounds can be interpreted differently. Therefore, the sedimentary processes of different microfacies can be reflected according to different lithofacies associations. Four vertical combinations are summarized in this paper, which respectively reflect different microfacies environments: subaqueous distributary channel, subaqueous distributary channel, estuarine bar and sheet sand. 


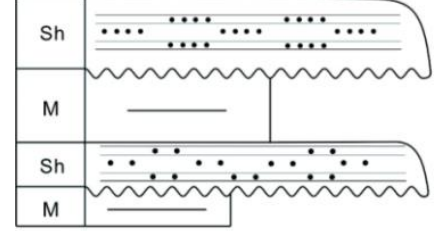

Type 1

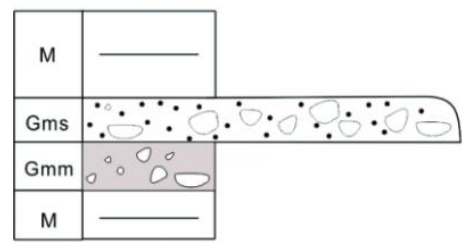

Type 3

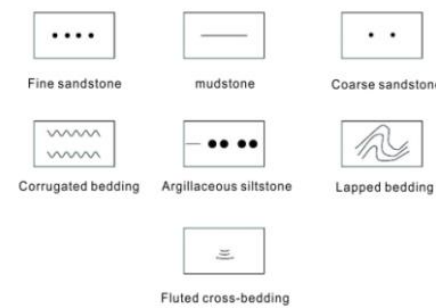

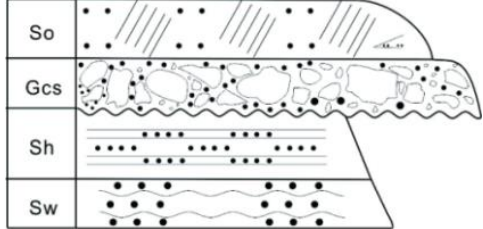

Type 2

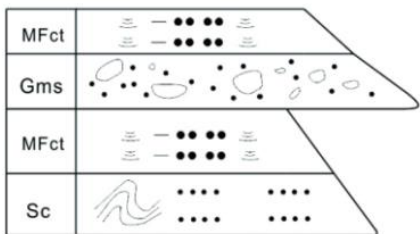

Type 4

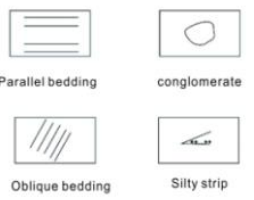

$\cdots$

Fig.2. Types of lithofacies assemblages in the second member of the Tengger formation, Jiergalangtu

(1) Type 1 (M-SH-M-SH) is composed of sandstone-mudstone with reverse cycle characteristics. The lithology of this type is mainly fine, coarse sandstone and mudstone, and there is a small amount of conglomerate between layers with good roundness. Parallel bedding of fine-coarse sandstone is developed, indicating rapid water flow.

(2) type 2 ( $\mathrm{Sw}$ - Sh - Gcs - So) sediments to breccia, coarse, medium and fine sandstone is given priority to, with a fine on the cycle characteristics, under development at the bottom of the brown wavy bedding sandstone, brown flat bedding sandstone upward development, also has a central particles flow deposits, sediment size mixture, the development of scour surface, the top of the development of brown inclined bedding sandstone, the type is not only containing silty belt and gravel belts. This suggests that this type of sediment may be mixed due to strong wind flow and water flow. This type mainly develops in the estuary bar.

(3) Type 3 (GMM-GMS-GMM-M) is mudstone at the bottom and gray-green argillaceous conglomerate at the top, with complex gravel composition, brown sandy conglomerate in the middle with poor sorting and round characteristics, and gray-black mudstone at the top with reverse cycles of fine at the bottom and coarse at the top, which is mainly developed between subaqueous distributional channels.

(4) type 4 (Sc - MFct - Gms - MFct) mainly fine sandstone and argillaceous siltstone and conglomerate is given priority to, lapped bedding fine sandstone and groove at the bottom of the cross-bedding silty mudstone are brown oil immersion, the central part of the sandy conglomerate and coping argillaceous siltstone are grey, with a tapering positive cycle, the combination is mainly exist in sand sheet.

\section{CONCLUSION}

According to the combination of lithofacies and sedimentary microfacies, four lithofacies assemblages are obtained in study area: type 1 (m-sh-m-sh), type 2 (sw-sh-gcs-so), type 3 (gmm-gms-gmm-m), type 4 (sc-mfct-gms-mfct), corresponding to underwater distributary channel, estuarine bar, underwater distributary channel, sheet sand microfacies, respectively.

\section{Acknowledgments}

This work was financially supported by National Natura 1 Science Foundation of China (Grant No.41772144), Ta lent Introduction Research Start-up Fund Project of Nort heast Petroleum University (2019KQ01)

\section{Reference}

1. Wu yong, Zhou lu, Zhang yiming, et al. Reservoir prediction of teng 2 in jidong area, Jiergalangtu sag [J]. Natural gas industry 2008,28 (11) : 53-55.

2. Yi dinghong, Shi lanting, Lei Ming et al. Analysis of hydrocarbon accumulation characteristics and main controlling factors in Baorao trough, Jiergalangtu sag $[\mathrm{J}]$. Xinjiang petroleum and natural gas, 2006,2(2): 15-19. 
3. Tang Jing, Fan Tingen, Fan Hongjun et al. Study on macro heterogeneity of Reservoirs in L16 Oil Field and its influence on thermal recovery of heavy oil [J]. Frontiers of Earth Science, 2016,8(5): 982-996.

4. $\mathrm{Yu}$ xinghe, $\mathrm{Qu}$ jianhua, Tan chengpeng et al. Fan delta conglomerate facies and genetic model of baikouquan formation, mahu depression [J]. Xinjiang petroleum geology, 2014,3 (6) : 619-627.

5. Niu daming, Zhang yunfeng, Liu guowen, et al. Sedimentary facies of the second member of the Tengger formation in Jirgalangtu, erlian basin [J]. Energy and environmental protection, 2020,3 (18) : $82-87$

6. Du wei, $\mathrm{Hu}$ zongquan, Liu guangxiang, et al. Petrographic characteristics of the wufeng formation of the upper ordovician, sichuan basin and its periphery [J]. Petroleum experimental geology, 2020,42 (3) : 399-404 